\title{
Threat of an invasive parasitic fly, the deer ked (Lipoptena cervi), to the reindeer (Rangifer tarandus tarandus): experimental infection and treatment
}

\author{
Sanna-Mari Kynkäänniemi ${ }^{1}$, Raine Kortet ${ }^{1,2}$, Laura Härkönen ${ }^{1}$, Arja Kaitala1, \\ Tommi Paakkonen², Anne-Mari Mustonen², Petteri Nieminen ${ }^{2,3}$, \\ Sauli Härkönen ${ }^{4}$, Hannu Ylönen ${ }^{5} \&$ Sauli Laaksonen ${ }^{6}$
}

1) Department of Biology, P.O. Box 3000, Fl-90014 University of Oulu, Finland

2) Faculty of Biosciences, University of Joensuu, P.O. Box 111, Fl-80101 Joensuu, Finland

3) Faculty of Medicine, Institute of Biomedicine, Department of Anatomy and Cell Biology, P.O. Box 5000, Fl-90014 University of Oulu, Finland

4) Finnish Forest Research Institute, Joensuu Research Unit, P.O. Box 68, Fl-80101 Joensuu, Finland

5) Department of Biological and Environmental Science, Konnevesi Research Station, P.O. Box 35, Fl-40014 University of Jyväskylä, Finland

6) Finnish Food Safety Authority EVIRA, Fish and Wildlife Health Research Unit, P.O. Box 517, Fl-90101 Oulu, Finland

Received 12 Nov. 2008, revised version received 27 Nov. 2009, accepted 2 Oct. 2009

Kynkäänniemi, S.-M., Kortet, R., Härkönen, L., Kaitala, A., Paakkonen, T., Mustonen, A.-M., Nieminen, P., Härkönen, S., Ylönen, H. \& Laaksonen, S. 2010: Threat of an invasive parasitic fly, the deer ked (Lipoptena cervi), to the reindeer (Rangifer tarandus tarandus): experimental infection and treatment. - Ann. Zool. Fennici 47: 28-36.

Range expansion of ectoparasites can cause parasites to attack new host species. In these cases it is important for the parasite to be able to adapt to the new environment and to reproduce on the host. For the host, it is crucial to hinder successfully the development of long-lasting parasitic relationship. The deer ked (Lipoptena cervi) is a novel ectoparasite for northern cervids. We investigated if the deer ked can use the reindeer (Rangifer tarandus) as a host and, if it can, whether antiparasitic treatment against this parasite would be available. Three groups of reindeer were monitored: two groups of 6 reindeer were infected with 300 flies per each individual; a control group comprised 6 animals. One of the infected groups was treated with subcutaneous ivermectin. At the end of the experiment the infestation rate of the infected animals was low. The reindeer in the non-treated group had both live and dead deer keds and also a single pupa while the ivermectin-treated reindeer had only dead deer keds. As some deer keds survived and reproduced, the deer ked can potentially use the reindeer as a host but antiparasitic treatment may be effective against this parasite.

\section{Introduction}

Invasion or range expansion of parasites requires that suitable hosts are available, as parasites cannot exist in isolation from their hosts (Wall 2007). Free-living invasive species have different 
life histories as compared with those of invasive ectoparasites (Boulinier et al. 2001): these include better dispersal ability because of their broader ecological requirements and tolerance (e.g. Mack et al. 2000, Sax \& Brown 2000). When encountering a new host, the parasite needs to overcome the physiological and immunological defences of the hosts to be able to attach and reproduce successfully (Moore 2002, Wall 2007). For blood-feeding ectoparasites, which infest large vertebrates, host density is the most crucial factor for the invasion, if these parasites use their hosts for dispersal (Boulinier et al. 2001). For these kinds of species, conditions on the host are usually stable with plenty of available resources. Therefore, their distribution is most likely constrained by life history stages outside the host (Lehane 2005). Thus, the new developing hostparasite relationships are affected not only by the host and its resistance against parasitism but also by external climatic and biotic factors the life stage is exposed to outside the host (Wall 2007).

The effects of parasite infections on the host depend on the intensity of infection, the virulence of the parasite and the resistance of the host animal (Moore 2002). Parasites can cause direct damage to the host's tissues, carry zoonotic diseases and indirectly affect the energy budget of the host by reducing its fitness. In general, host-specialist ectoparasites do only minor damage to the host, while it is commonly assumed that non-specialist ectoparasites can be more virulent, especially when they infect new host species (Wall 2007).

Arthropod parasites are usually ectoparasites. The deer ked (Lipoptena cervi) is an ectoparasitic louse fly capable of infecting various cervids (Haarløv 1964, Kaunisto et al. 2009). It was detected in south-eastern Finland in the 1960s, presumably originating from Russia and since then it has been spreading towards larger areas in Finland (Hackman 1977, Kaitala et al. 2009). According to Reunala et al. (1980) Linné described the deer ked in Sweden in the 18th century. This louse fly entered Norway from the south-east in 1983 (Ottesen 2007).

In Finland, the principal host of the deer ked is the moose (Alces alces), usually with 200010000 parasites per host in areas, where the deer ked is abundant (T. Paakkonen unpubl. data).
The moose has been a beneficial host species for the deer ked allowing it to widen its distribution, as cervids are known to migrate long distances (Cederlund \& Liberg 1995). As the deer ked has spread rapidly towards the northern latitudes in Finland, it can be considered a host-dependent invasive species (Hackman et al. 1983, Kaitala et al.2009). At present, the northern distribution limit of this louse fly is in the southern part of the Finnish reindeer herding area, at approximately $65^{\circ} \mathrm{N}$ (Kaitala et al. 2009) but there have been occasional discoveries in areas situated two hundred kilometres further north. Outside the current range of the deer ked, there are suitable climatic conditions and environments, where pupal development would be possible and suitable hosts available (Härkönen et al. 2010).

In addition to the moose, the deer ked can utilize, e.g., the roe deer (Capreolus capreolus) and the red deer (Cervus elaphus) as hosts (Ivanov 1974). Samples collected recently from skins of Finnish wild forest reindeer (Rangifer tarandus fennicus) and their bedding sites on the snow contained deer keds or a few pupae, and the same was also observed for semi-domesticated reindeer (R.t.tarandus) in the southern part of the reindeer herding area (Kaunisto et al. 2009). Previously, Kettle and Utsi (1955) observed reindeer infested with deer keds in Scotland. Moreover, Ivanov (1981) reported that deer keds could also infect cattle (Bos taurus), sheep (Ovis aries) and horses (Equus caballus) that grazed the forests in Belarus. The numbers of keds on cattle varied between $166 \pm 12$ and $315 \pm 9$ in 1973-1979 and 5-10 keds/cow were sufficient to cause restlessness to the hosts.

The deer ked and some other louse flies differ from most other ectoparasites because they shed their wings after they have found a host animal. Both female and male deer keds attack animals passing by and live on the host feeding on its blood (Hackman et al. 1983). Reproduction of the deer ked takes place in the fur of the host animal and females deposit one puparium at a time (Haarløv 1964). It has been suggested that the breeding of the deer ked could last for up to 8-10 months (Kaitala et al. 2007, but see Popov 1965). Adult deer keds emerge in the areas, where they dropped as pupae in the preceding autumn and winter (Haarløv 1964). 
Also humans are susceptible to numerous attacks of the deer ked during professional or recreational forest use (Kortet et al. 2010). The bites can cause allergic dermatitis and secondary infections to sensitized individuals (Ivanov 1974, Rantanen et al. 1982, Reunala et al. 2008). The deer ked has also been proposed to act as a vector for bacteria of the Bartonella genus (Dehio et al. 2004). Deer keds are likely to have stressful effects on their hosts and affect the health of animals by causing scratching and associated skin changes (Ivanov 1981). Skin and hide damages of moose have been connected to chronic deer ked infection (Laaksonen et al. 2008a).

Antiparasitic treatment with ivermectin is routinely used in reindeer management in Finland (Laaksonen et al. 2008b). Ivermectin is a synthetic derivative of avermectins without antibacterial activity (Dourmishev et al. 2005). It affects endo- and ectoparasites by preventing the conduction of nerve impulses in synapses gated by glutamate or $\gamma$-aminobutyric acid causing eventual paralysis. In vertebrates, these synapses are not located in the peripheral nervous system (unlike in invertebrates) but only in the central nervous system. As ivermectin cannot cross the blood-brain barrier it is harmless to vertebrates.

As the deer ked is a potential threat to reindeer health and husbandry, this study focused on two crucial questions: (1) are deer keds able to attach on reindeer and use them as hosts for feeding and reproduction, and (2) could this parasite be controlled by using the antiparasitic agent ivermectin? The latter would be logistically possible as the semi-domesticated reindeer are regularly subjected to annual treatment and medication against other ecto- and endoparasites (Laaksonen et al. 2008b).

\section{Material and methods}

\section{Experimental procedures}

The study was carried out in the Zoological Gardens of the University of Oulu, Finland $\left(65^{\circ} \mathrm{N}\right.$, $25^{\circ} \mathrm{E}$ ) with permission of the Committee on Animal Experiments of the University of Oulu (licence decision STH378A; 16.5.2007/ESLH-
2007-03532/Ym-23) between 29 May and 13 Dec. 2007. The experimental animals were 18 adult reindeer (11 females and 7 males; age $2.8 \pm 0.6$ years). On 29 May, the reindeer were assigned into three experimental groups with an equal sex ratio and average age (Infection group, Infection \& Medication group and Control group). Each reindeer was fitted with a collar with individual colouring and a numbered ear tag for identification.

At the start of the experiment, on 29 May, before the reindeer were infected with deer keds, the animals were treated against other possible endo- and ectoparasites with subcutaneous (sc) ivermectin $\left(0.2 \mathrm{mg} \mathrm{kg}^{-1}\right.$; Bimectin vet ${ }^{\circledR}$, Vetpharma AB, Lund, Sweden/Vetcare Oy, Vantaa, Finland) and topical deltametrin (75 mg/reindeer; pour-on lotion on dorsal skin; Coopersect spot on vet $^{\circledR}$, Schering Plough, Ballerup, Denmark). The ivermectin treatment was repeated on 13 June. The males were castrated on 29 May to prevent rut behaviour in autumn as it can be disturbing and result in injuries or stress to other reindeer. Moreover, the handling of males in rut can be difficult. The reindeer were fed ad libitum with a commercial diet [Poron-Herkku, Rehuraisio, Espoo, Finland, energy content 11.7 MJ metabolizable energy $\mathrm{kg}$ dry matter ${ }^{-1}$ ] supplemented with lichen (Cladonia spp.), hay and dried birch (Betula spp.) and willow (Salix spp.) leaves.

The animals of Infection and Infection \& Medication groups were immobilized in a handling crib without sedation for the experimental infections. Each reindeer in Infection and Infection \& Medication groups was similarly infected on six occasions between 16 Aug. and 27 Sep. with an equal number of deer keds $(35,35,35$, $45,35,115, n=300 /$ reindeer; Table 1$)$. The keds were applied on the anterior back of each animal. The control animals were immobilized similarly but did not receive parasites. During the subsequent infections, signs of previously implanted deer keds were examined. Because there were no previous data to indicate how the reindeer would react to the deer ked infection, we used infection intensity approximately 20 times lower than previously observed in wild Finnish moose (T. Paakkonen unpubl. data). The number of deer keds was relatively low in order to mimic the situation in nature in the southern reindeer herding 
area and to avoid unexpected stress reactions of the reindeer. Some keds $(n=1260)$ were reared at the University of Oulu from wild-collected pupae from various parts of Finland $\left(60-65^{\circ} \mathrm{N}\right)$. The numbers of deer keds used for the infection on specific dates depended on their hatching rate. Due to the low emergence rate, deer keds $(n=2340)$ collected by hand in the communes of Rantsila $\left(64^{\circ} \mathrm{N}\right)$ and Liperi $\left(62^{\circ} \mathrm{N}\right)$ were also allocated equally to both infection groups. The genders of the keds were not determined. All reindeer groups were kept at natural ambient temperature and photoperiod in their own enclosures $\left(570 \mathrm{~m}^{2}\right)$ to prevent deer ked contamination between the groups.

On 6 Nov. 2007, Infection \& Medication group was treated with sc ivermectin $(0.2$ $\left.\mathrm{mg} \mathrm{kg}^{-1}\right)$. Infection and Control groups were given equivolume $0.85 \%$ saline injections as a placebo treatment. The experiment was terminated between 10 and $13 \mathrm{Dec}$., and the reindeer were stunned with a bolt pistol and killed by exsanguination. An individual (ID no. 13) displaying strong stress, behavioural and physical reactions (i.e. hair loss) probably caused by the infection, was killed earlier on 24 Oct. for ethical reasons. The pelts were examined in detail by cutting the hair with scissors and calculating the numbers of live and dead deer keds and other possible ectoparasites.

\section{Statistical analysis}

The differences in the numbers of live and dead deer keds between Infection group and Infection \& Medication group were tested with the non-parametric Mann-Whitney $U$-test using the SPSS program (ver. 16.0, SPSS Inc., Chicago, IL). Differences were considered statistically significant at $p<0.05$. The results are presented as mean $\pm \mathrm{SE}$.

\section{Results}

Immediately after the experimental infections the deer keds disappeared into the reindeer pelts and dropped their wings (Fig. 1a). During subsequent infection dates, live deer keds that had consumed blood (flat, more lightly-coloured, distended abdomen) and females that contained developing larvae (round, dark, distended abdomen) could be observed in the reindeer hair. In both Infection and Infection \& Medication groups the reindeer scratched themselves leaving bare patches and chafes in the pelt. Also hair discoloration caused probably by deer ked faeces could be observed, especially in white individuals.

No deer keds were found on Control group at the end of the experiment (Table 2). Infection group had $6 \pm 3$ live and $5 \pm 1$ dead flies per reindeer (total $11 \pm 3$ ) and Infection \& Medication group had no live but $17 \pm 3$ dead flies per reindeer. The total number of deer keds at the end of the experiment did not differ statistically between Infection and Infection \& Medication groups (Mann-Whitney $U$-test, reindeer no. 13 excluded: $U=10.0, n=5-6, p=0.429)$. The differences in the numbers of live (Mann-Whitney $U$-test, reindeer no. 13 excluded: $U=0.000, n$ $=5-6, p=0.004)$ and dead deer keds (MannWhitney $U$-test, reindeer no. 13 excluded: $U=$ $3.0, n=5-6, p=0.030$ ) between Infection group and Infection \& Medication group were statistically significant. Those differences remained significant also when reindeer no. 13 was included (data not shown).

The total recovery of deer keds in Infection and Infection \& Medication groups was 4.7\%: $1.1 \%$ for live and $3.6 \%$ for dead keds. The recovery of live deer keds in Infection group was $2.1 \%$ (including reindeer no. 13). Only one pupa could be found from an individual reindeer of Infection group. No other ectoparasites were observed in any of the study groups.

Table 1. Infection dates and numbers of transplanted deer keds/reindeer.

\begin{tabular}{lccrrrrr}
\hline Group & 16 Aug. & 23 Aug. & 4 Sep. & 17 Sep. & 20 Sep. & 27 Sep. & Total \\
\hline Infection & 35 & 35 & 35 & 45 & 35 & 115 & 300 \\
Infection \& Medication & 35 & 35 & 35 & 45 & 35 & 115 & 300 \\
Control & 0 & 0 & 0 & 0 & 0 & 0 & 0 \\
\hline
\end{tabular}



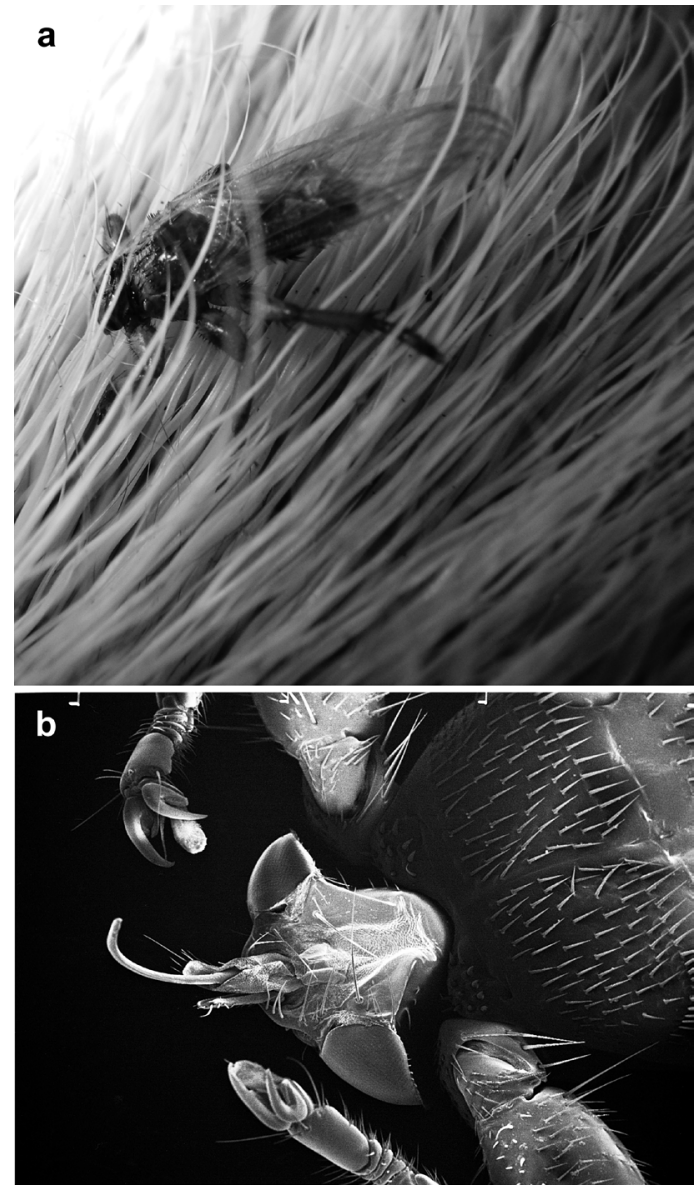

Fig. 1. (a) A deer ked entering the fur on the dorsum of a reindeer during the experimental infection (photo: Sauli Laaksonen). Note that the ked has not yet lost its wings. The reindeer has denser winter pelage (guard hair count $1700 / \mathrm{cm}^{2}$ on the back; Timisjärvi et al. 1984) than the moose (250 hairs $/ \mathrm{cm}^{2}$; Sokolov \& Chernova 1987). (b) SEM image of a deer ked (photo: Paavo Niutanen). Note the shape and sharpness of the claws which enable attachment to the fur of the host.

\section{Discussion}

Our main results were: (i) deer keds seem to be able to attach to reindeer and use them as hosts, and (ii) the parasitism could be controlled with ivermectin. However, the survival rates of the deer keds were very low and only a single pupa was observed in the pelt of an individual reindeer at the end of the study. Nevertheless, even these low rates of survival and reproduction suggest that the deer ked could potentially become a parasite of reindeer and reproduce on them.
This conclusion is supported by field observations, where few pupae dropped on bedding sites of reindeer were observed in Hyrynsalmi municipality $\left(65^{\circ} \mathrm{N}\right)$ in winter 2008 (Kaunisto et al. 2009). Our findings may have significant applications to reindeer herding, as deer keds have already expanded their northern distribution limit into the southern area of reindeer husbandry (Kaitala et al. 2009). Preliminary behavioural observations (S.-M. Kynkäänniemi unpubl. data) and data from another host species, the moose (Ivanov 1981, Laaksonen 2006), suggest that the deer ked could cause considerable stress to its host. Due to strong indications of stress that may have been caused by the deer keds, one female reindeer in Infection group had to be killed for ethical reasons before the end of the experiment.

From the point of view of invasive parasite species the situation can be described as follows: the deer ked, infesting primarily the moose in Finland, has reached areas where other cervids, such as the reindeer, are available as potential hosts. A dense moose population may be able to support the existence and spread of the deer ked in the north. However, for the alternative host species, the reindeer, this would mean an increasing number of deer ked attacks. According to the present study, the deer ked, although potentially irritating for reindeer, may not be well adapted to infest reindeer for longer periods. Thus, it is possible that slower adaptation of the deer ked to the new host species or coevolution with it could occur in the north where the reindeer is at present the principal potential cervid host.

An important factor regarding the possible health effects of the deer ked on the reindeer is that the time period when host-seeking deer keds are the most abundant in nature is during Aug.-Sep. (Ivanov 1981), immediately after the mass appearance of other blood-consuming insects (Helle \& Tarvainen 1984). It is known that summer disturbance caused by insects reduces the grazing time and increases the energy expenditure of reindeer (Weladji et al. 2003). Thus, a novel type of disturbance leading to continuing insect harassment in autumn could possibly affect reindeer winter survival in a deleterious manner. In the present study, bare patches 
and chafes were observed in the fur, which could cause detrimental health effects especially in harsh winter conditions. For example, McLaughlin and Addison (1986) reported increased heat loss and a poor physiological condition in captive moose with loss of winter hair caused by attempts to remove winter ticks (Dermacentor albipictus).

It is worth noting that while deer keds were recently observed in the Finnish reindeer husbandry area (Laaksonen et al. 2007, 2008a), the dispersion of deer keds on reindeer further to the north could be limited by the seasonal feeding behaviour of reindeer herds. The reindeer graze in different areas in spring and autumn (Laaksonen 2006) and, thus, under this scenario, the flies that have fallen in winter/spring as pupae would emerge in the next autumn in areas with less seasonal reindeer grazing and could be unable to find reindeer as hosts. However, the moose population is quite dense in the southern area of the reindeer husbandry (Pusenius et al. 2008) and, thus, deer keds can possibly continue expanding their distribution area.

As the number of live deer keds on the reindeer decreased dramatically during the experiment, it could be suggested that as compared with e.g., the moose, the reindeer could have a natural ability to partly resist and discard deer keds from its skin similar to the partial resistance against the sheep ked (Melophagus ovinus) in experimentally infected sheep (Nelson 1962). The density of hair in the winter pelage of the reindeer is higher than that of the moose (Fig. 1a; Timisjärvi et al. 1984, Sokolov \& Chernova 1987). A very dense hair could hypothetically prevent the deer keds from gaining sufficient access to skin for feeding on blood. Reindeer might also be able to remove the deer keds that are unable to intrude through the dense underfur even though the sharp claws of the deer ked enable it to attach to hairs (Fig. 1b). This may also help another reindeer subspecies, the wild-forest reindeer, to resist deer ked infection. An alternative cause for the decline in the numbers of live keds could be the complicated route of experimental transplantation (i.e. stored pupae and transported flies) causing an impaired physiological condition of the deer keds used in the experiment. In addition, the natural course of deer ked infection must also be taken into account, as according to Ivanov (1981), the duration of parasitism is between 120-180 days for an individual fly. Thus, it is possible that some of the flies used in the experiment had reached the end of their lifespan at the end of the study. We did not observe any live deer keds from the pelts of Infection \& Medication group, indicating that ivermectin would be efficient against deer keds. It has a broad spectrum of antiparasitic activity

Table 2. The numbers of live and dead deer keds and pupae per study group (mean \pm SE) and gender of the experimental reindeer at the end of the experiment on 10-13 Dec. 2007. ${ }^{a}=$ this reindeer was removed from the experiment on 24 Nov. for ethical reasons. ${ }^{*}=$ significant $(p<0.05)$ difference between Infection and Infection \& Medication groups.

\begin{tabular}{|c|c|c|c|c|}
\hline ID number and gender & Live keds & Dead keds & Total & Pupae \\
\hline Infection & $6 \pm 3^{*}$ & $5 \pm 1^{*}$ & $11 \pm 3$ & 1 \\
\hline 4 우 & 1 & 11 & 12 & \\
\hline 7 우 & 2 & 6 & 8 & \\
\hline $120^{7}$ & 10 & 1 & 11 & 1 \\
\hline 13Oa & 6 & 2 & 8 & \\
\hline $170^{7}$ & 18 & 5 & 23 & \\
\hline 189 & 1 & 3 & 4 & \\
\hline Infection \& Medication & $0^{*}$ & $17 \pm 3^{*}$ & $17 \pm 3$ & 0 \\
\hline 19 & 0 & 21 & 21 & \\
\hline 29 & 0 & 27 & 27 & \\
\hline $50^{7}$ & 0 & 10 & 10 & \\
\hline $100^{7}$ & 0 & 26 & 26 & \\
\hline $110^{n}$ & 0 & 10 & 10 & \\
\hline 15 우 & 0 & 9 & 9 & \\
\hline Control (3\%, 60', 8ᄋ, 9ᄋ, 140", 16\%) & 0 & 0 & 0 & 0 \\
\hline
\end{tabular}


against gastrointestinal nematodes, lungworms, warbles, mange mites and other nematodes and arthropods in cattle, other livestock and reindeer (Oksanen 1999). The endectocidid antiparasitic treatment is at present routinely used in Finland almost in the whole area of reindeer husbandry in late autumn and early winter, when the breeding animals are treated with ivermectin. Thus, the impact of the deer ked on reindeer husbandry could probably be controlled but the high intensity of parasitism and potential disturbance on wild cervids will possibly remain. So far, there is virtually no information available on the impact of the deer ked on the health of wild cervids (but see Kaunisto et al. 2009). While ivermectin seemed to be efficient against deer keds, more studies on the basic biology of the species are required for the exact timing of the treatment. Moreover, the effectiveness of the medication against the deer ked in natural conditions and against a higher number of parasites should be explored in controlled experiments without forgetting the possible emergence of drug resistance against ivermectin (Shoop 1993) and environmental aspects (reviewed by Hrabok 2006).

The general pattern of the potential establishment of the deer ked in northern environments such as the Finnish Lapland may be that the principal supporting or determining factors in the spread of the deer ked are the climate change together with the possible increase in moose population densities. To support this, other ectothermic species have been observed to widen their distribution northward due to the global warming (Beaumont \& Hughes 2002, Vanhanen et al. 2007). In fact, in the circumpolar area, there are observations on increasing temperatures, precipitation and anthropogenic landscape change, which can cause changes in plant and insect phenologies - the major factors affecting the cervid populations in arctic areas (Vors $\&$ Boyce 2009). Once the deer ked has established itself in the area of reindeer husbandry, the development of pupae seems to be possible there (Härkönen et al. 2010, A. Kaitala unpubl. data). Further research is needed to verify if the potentially shorter flying period in the north as compared with that in the present range would be long enough for emerging deer keds to find suitable hosts. For alternative host species, such as the reindeer, the development of a long-term host-parasite interaction is a long-lasting adaptive process. However, if the deer ked will be established in Lapland, it could cause an increasing threat of parasitism to the reindeer similar to southern Scandinavia, where the parasite can be found in all available cervid host species ( $\mathrm{P}$. Välimäki unpubl. data).

\section{Acknowledgements}

We want to thank Jari Ylönen, Milla Solismaa, Anu Ruohomäki, Anna Honkanen, Pertti Rautio and the Biological Research Facility Unit of the University of Oulu for their help during the experiment. For good comments on the manuscript we are grateful to Heikki Pöykkö and Sami Kivelä. We thank Paavo Niutanen for providing us the scanning microscope images of the deer ked morphology. We thank also the University of Oulu, Vetcare Oy and the Ministry of Agriculture and Forestry (Makera) for financial support. The experiment complied with the current laws of Finland.

\section{References}

Beaumont, L. J. \& Hughes, L. 2002: Potential changes in the distributions of latitudinally restricted Australian butterfly species in response to climate change. - Global Change Biology 8: 954-971.

Bequaert, J. 1953: The Hippoboscidae or louse-flies (Diptera) of mammals and birds. Part I. Structure, physiology and natural history. - Entomologica Americana 32/33: $1-442$.

Boulinier, T., McCoy, K. \& Sorci, G. 2001: Dispersal and parasitism. - In: Clobert, J., Danchin, E., Dhondt, A. A. \& Nichols, J. D. (eds.), Dispersal: 169-179. Oxford University Press, Oxford.

Cederlund, G. \& Liberg, O. 1995: Rådjuret, viltet, ekologin och jakten. - Almqvist \& Wiksell, Uppsala.

Dehio, C., Sauder, U. \& Hiestand, R. 2004: Isolation of Bartonella schoenbuchensis from Lipoptena cervi, a blood-sucking arthropod causing deer ked dermatitis. Journal of Clinical Microbiology 42: 5320-5323.

Dourmishev, A. L., Dourmishev, L. A. \& Schwartz, R. A. 2005: Ivermectin: pharmacology and application in dermatology. - International Journal of Dermatology 44: 981-988.

Haarløv, N. 1964: Life cycle and distribution pattern of Lipoptena cervi (L.) (Dipt., Hippobosc.) on Danish deer. - Oikos 15: 93-129.

Hackman, W. 1977: Hirven täikärpänen ja sen levittäytyminen Suomeen. - Luonnon Tutkija 81: 75-77.

Hackman, W., Rantanen, T. \& Vuojolahti, P. 1983: Immigration of Lipoptena cervi (Diptera, Hippoboscidae) in Finland, with notes on its biology and medical significance. - Notulae Entomologicae 63: 53-59. 
Härkönen, L., Härkönen, S., Kaitala, A., Kaunisto, S., Kortet, R., Laaksonen, S. \& Ylönen, H. 2010: Predicting range expansion of an ectoparasite - the effect of spring and summer temperatures on deer ked (Lipoptena cervi, Diptera: Hippoboscidae) performance along a latitudinal gradient. - Ecography. [In press].

Helle, T. \& Tarvainen, T. 1984: Effects of insect harassment on weight gain and survival in reindeer calves. - Rangifer 4: 24-27.

Hrabok, J. T. 2006: Nematode parasites of reindeer in Fennoscandia. Population dynamics, anthelmintic control and its environmental impact. - Ph.D. thesis, Faculty of Veterinary Medicine and Animal Science, Swedish University of Agricultural Sciences, Uppsala.

Ivanov, V. I. [Иванов, В. И.] 1974: [On the damage done by Lipoptena cervi L. (Diptera, Hippoboscidae) in Byelorussia]. - Parazitologia VIII: 252-253. [In Russian].

Ivanov, V. І. [Иванов, В. И.] 1981: [Spread of the deer ked Lipoptena cervi L. (Diptera, Hippoboscidae) in Belarus, its biology and deleterious effects]. - Ph.D. thesis, Institute of Parasitology and Trophic Medicine, Veterinary Academy of Moscow. [In Russian].

Kaitala, A., Härkönen, S., Laaksonen, S., Niemelä, P. \& Ylönen, H. 2007: Deer ked project - a broadly-based interdisciplinary research project in Finland. - In: Härkönen, S. (ed.), Workshop Schedule and Abstracts of the 1st Nordic Workshop on Biology, Applied Importance and Current Research on the Deer Ked, November 26-27, 2007, Joensuu, Finland: 11-12.

Kaitala, A., Kortet, R., Härkönen, S., Laaksonen, S., Härkönen, L., Kaunisto, S. \& Ylönen, H. 2009: Deer ked, an ectoparasite of moose in Finland: A brief review of its biology and invasion. - Alces 45: 85-88.

Kaunisto, S., Kortet, R., Härkönen, L., Härkönen, S., Ylönen, H. \& Laaksonen, S. 2009: New bedding site examination-based method to analyse deer ked (Lipoptena cervi) infection in cervids. - Parasitology Research 104: 919-925.

Kettle, D. S. \& Utsi, M. N. P. 1955: Hypoderma diana (Diptera, Oestridae) and Lipoptena cervi (Diptera, Hippoboscidae) as parasites of reindeer (Rangifer tarandus) in Scotland with notes on the second-stage larva of Hypoderma diana. - Parasitology 45: 116-120.

Kortet, R., Härkönen, L., Hokkanen, P., Härkönen, S., Kaitala, A., Kaunisto, S., Laaksonen, S., Kekäläinen, J. \& Ylönen, H. 2010: Experiments on the ectoparasitic deer ked that often attacks humans; preferences for body parts, colour and temperature. - Bulletin of Entomological Research. [In press].

Laaksonen, S. 2006: Hirveän harmillinen hirvikärpänen. Kaari 3: 12-13.

Laaksonen, S., Paakkonen, T., Kortet, R., Mustonen, A.-M., Nieminen, P., Härkönen, L., Solismaa, M., Kaitala, A., Ylönen, H., Aho, J. \& Härkönen, S. 2007: Deer ked - a threat to reindeer welfare? - In: Härkönen, S. (ed.), Workshop Schedule and Abstracts of the 1st Nordic Workshop on Biology, Applied Importance and Current Research on the Deer Ked, November 26-27, 2007, Joensuu, Finland: 13-14.

Laaksonen, S., Kortet, R., Härkönen, S. \& Ylönen, H. 2008a:
Hirvikärpänen - poron ja metsäpeuran uusi kiusa. Suomen eläinlääkärilehti 114: 512-515.

Laaksonen, S., Oksanen, O., Orro, T., Norberg, H., Nieminen, M. \& Sukura, A. 2008b: Efficacy of different treatment regimes against setariosis (Setaria tundra, Nematoda: Filarioidea) and associated peritonitis in reindeer. - Acta Veterinaria Scandinavica 50: 49.

Lehane, M. 2005: The biology of blood-sucking insects. Cambridge University Press, UK.

Mack, R. N., Simberloff, D., Lonsdale, W. M., Evans, H., Clout, M. \& Bazzaz, F. A. 2000: Biotic invasions: causes, epidemiology, global consequences and control. - Ecological Applications 10: 689-710.

McLaughlin, R. F. \& Addison, E. M. 1986: Tick (Dermacentor albipictus)-induced winter hair-loss in captive moose (Alces alces). - Journal of Wildlife Diseases 22: $502-510$.

Moore, J. 2002: Parasites and behavior of animals. Oxford University Press, USA.

Nelson, W. A. 1962: Development in sheep of resistance to the ked Melophagus ovinus (L.). I. Effects of seasonal manipulation of infestations. - Experimental Parasitology 12: 41-44.

Oksanen, A. 1999: Endectocide treatment of the reindeer. Rangifer Special Issue 11: 1-56.

Ottesen, B. 2007: The past and future expansion of the deer ked (Lipoptena cervi) in Norway - an online internet mapping project. - In: Härkönen, S. (ed.), Workshop Schedule and Abstracts of the 1st Nordic Workshop on Biology, Applied Importance and Current Research on the Deer Ked, November 26-27, 2007, Joensuu, Finland: 17.

Popov, A. V. [Попов, A. B.] 1965: [The life cycle of louse-flies Lipoptena cervi L. and Stenepteryx hirundinis L. (Diptera, Hippoboscidae)]. - Entomologicheskoe Obozrenie XLIV: 573-583. [In Russian].

Pusenius, J., Pesonen, M., Tykkyläinen, R., Wallén, M. \& Huittinen, A. 2008: Hirvikannan koko ja vasatuotto vuonna 2006. Riista- ja kalatalous - Selvityksiä 5/2008: $7-14$.

Rantanen, T., Reunala, T., Vuojolahti, P. \& Hackman, W. 1982: Persistent pruritic papules from deer ked bites. Acta Dermato-Venereologica 62: 307-311.

Reunala, T., Rantanen, T., Vuojolahti, P. \& Hackman, W. 1980: Hirvikärpäsihottuma. - Duodecim 96: 897-902.

Reunala, T., Laine, M., Vornanen, M. \& Härkönen, S. 2008: Hirvikärpäsihottuma - maanlaajuinen riesa. - Duodecim 124: 1607-1613.

Sax, D. F. \& Brown, J. H. 2000: The paradox of invasion. Global Ecology \& Biogeography 9: 363-371.

Shoop, W. L. 1993: Ivermectin resistance. - Parasitology Today 9: 154-159.

Sokolov, V. E. \& Chernova, O. F. 1987: Morphology of the skin of moose (Alces alces L.). - Swedish Wildlife Research Suppl. 1: 367-375.

Timisjärvi, J., Nieminen, M. \& Sippola, A. L. 1984: The structure and insulation properties of the reindeer fur. - Comparative Biochemistry and Physiology A 79: 601-609.

Vanhanen, H., Veteli, T., Päivinen, S., Kellomäki, S. \& Niemelä, P. 2007: Climate change and range shifts in 
two insect defoliators: gypsy moth and nun moth - a model study. - Silva Fennica 41: 621-638.

Vors, L. S. \& Boyce, M. S. 2009: Global declines of caribou and reindeer. - Global Change Biology 15: 2626-2633.

Wall, R. 2007: Ectoparasites: future challenges in a changing world. - Veterinary Parasitology 148: 62-74.

Weladji, R. B., Holand, Ø. \& Almøy, T. 2003: Use of climatic data to assess the effect of insect harassment on the autumn weight of reindeer (Rangifer tarandus) calves. - Journal of Zoology 260: 79-85. 